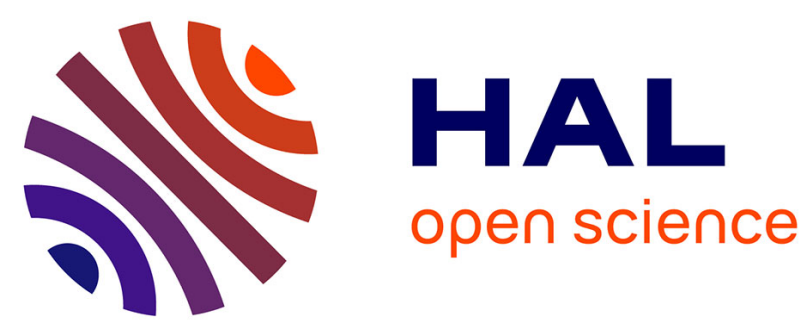

\title{
West Central African Peoples: Survey of Radiocarbon Dates over the Past 5000 Years
}

Richard Oslisly, Ilham Bentaleb, Charly Favier, Michel Fontugne, Jean

François Gillet, Julie Morin-Rivat

\section{- To cite this version:}

Richard Oslisly, Ilham Bentaleb, Charly Favier, Michel Fontugne, Jean François Gillet, et al.. West Central African Peoples: Survey of Radiocarbon Dates over the Past 5000 Years. Radiocarbon, 2013, 55 (03), pp.1377-1382. 10.1017/S003382220004830X . hal-01970137

\section{HAL Id: hal-01970137 \\ https://hal.science/hal-01970137}

Submitted on 30 Oct 2020

HAL is a multi-disciplinary open access archive for the deposit and dissemination of scientific research documents, whether they are published or not. The documents may come from teaching and research institutions in France or abroad, or from public or private research centers.
L'archive ouverte pluridisciplinaire HAL, est destinée au dépôt et à la diffusion de documents scientifiques de niveau recherche, publiés ou non, émanant des établissements d'enseignement et de recherche français ou étrangers, des laboratoires publics ou privés. 


\title{
AUTHOR'S CORRECTED PROOF
}

This article has been approved for publication.

\section{WEST CENTRAL AFRICAN PEOPLES: SURVEY OF RADIOCARBON DATES OVER THE PAST 5000 YEARS}

\author{
Richard Oslisly ${ }^{1,2}$ • Ilham Bentaleb ${ }^{3}$ Charly Favier $^{3}$ - Michel Fontugne ${ }^{4}$ Jean François Gillet ${ }^{5}$ \\ Julie Morin-Rivat ${ }^{5}$
}

\begin{abstract}
Tracing human history in west central Africa suffers from a scarcity of historical data and archaeological remains. In order to provide new insight into this problem, we reviewed 733 radiocarbon dates of archaeological sites from the end of the Late Stone Age, Neolithic Stage, and Early and Late Iron Age in Cameroon, Gabon, Central African Republic, Equatorial Guinea, Republic of Congo, and the western Democratic Republic of Congo. This review provides a spatiotemporal framework of human settlement in the forest biome. Beyond the well-known initial spread of Iron Age populations through central African forests from $2500 \mathrm{cal}$ BP, it depicts the geographical patterns and links with the cultural evolution of the successive phases of human expansion from 5000 to $3000 \mathrm{cal} \mathrm{BP}$ and then from 3000 to $1600 \mathrm{cal} \mathrm{BP}$, of the hinterland depopulation from 1350 to $860 \mathrm{cal} \mathrm{BP}$, and of recolonization up to $500 \mathrm{cal} \mathrm{BP}$.
\end{abstract}

\section{INTRODUCTION}

In the western part of central Africa, archaeological surveys during the last 3 decades have provided more than 50 scientific publications (see Appendix S1, online Supplementary file) contributing to our knowledge on cultural changes and their timing. These studies of ancient human occupation sites reveal 4 cultural changes during the last 5000 yr: the end of the Late Stone Age (LSA) around 3500 cal BP supplanted by a Neolithic stage from 3500 to 1900 cal BP, itself progressively replaced by the Early Iron Age (EIA) from 2800 to 1000 cal BP, followed by the Late Iron Age (LIA) between $1000 \mathrm{cal} \mathrm{BP}$ and the 18th century (colonial period). Previous studies conducted in central and eastern Gabon and southern Cameroon (Oslisly 2001, 2006; Eggert et al. 2006) have shown an increase in the number of radiocarbon dates from 2100 to $1700 \mathrm{cal}$ BP followed by an abrupt decrease in human occupation sites from 1600 to $1000 \mathrm{cal} \mathrm{BP}$, and a total absence of ${ }^{14} \mathrm{C}$ dates from 1350 to $860 \mathrm{cal}$ BP in the forest hinterland (Oslisly 1998, 2001; Wotzka 2006). This phase ends at $900 \mathrm{cal}$ BP when the LIA populations settled in the area.

Here, we review the available literature in order to create a database of human occupation in west central Africa. This database was then used to refine the chronosequence of the cultural changes over the past $5000 \mathrm{yr}$.

\section{STUDY AREA}

The study area encompassed 6 countries of central Africa (the southern half of Cameroon, continental Equatorial Guinea, Gabon, Republic of Congo, the western part of the Democratic Republic of Congo, and the southwest Central African Republic) between latitudes $7^{\circ} \mathrm{N}-6^{\circ} \mathrm{S}$ and longitudes $9^{\circ} \mathrm{E}-20^{\circ} \mathrm{E}$. The 2 current major biomes of the region are mixed and dense forests and savannas (Figure 1).

${ }^{1}$ IRD, Institut de Recherche pour le Développement, UMR 208-IRD/MNHN, Patrimoines locaux, Agence Nationale des Parcs Nationaux, BP 20379 Libreville, Gabon.

${ }^{2}$ Corresponding author. Email: richard.oslisly@ird.fr.

${ }^{3}$ Université de Montpellier 2, CNRS, ISEM, Place Eugene Bataillon, 34095 Montpellier, France.

${ }^{4}$ Laboratoire des Sciences du Climat et de l'Environnement, UMR 8212 CNRS CEA/UVSQ Domaine du CNRS, 91190 Gifsur-Yvette, France.

${ }^{5}$ Université de Liège, Gembloux Agro-Bio Tech, Laboratoire de Foresterie des Régions tropicales et subtropicales, Passage des Déportés 2, B-5030 Gembloux, Belgium.

(c) 2013 by the Arizona Board of Regents on behalf of the University of Arizona

Proceedings of the 21st International Radiocarbon Conference edited by A J T Jull \& C Hatté

RADIOCARBON, Vol 55, Nr 3-4, 2013, p 1-xxx 


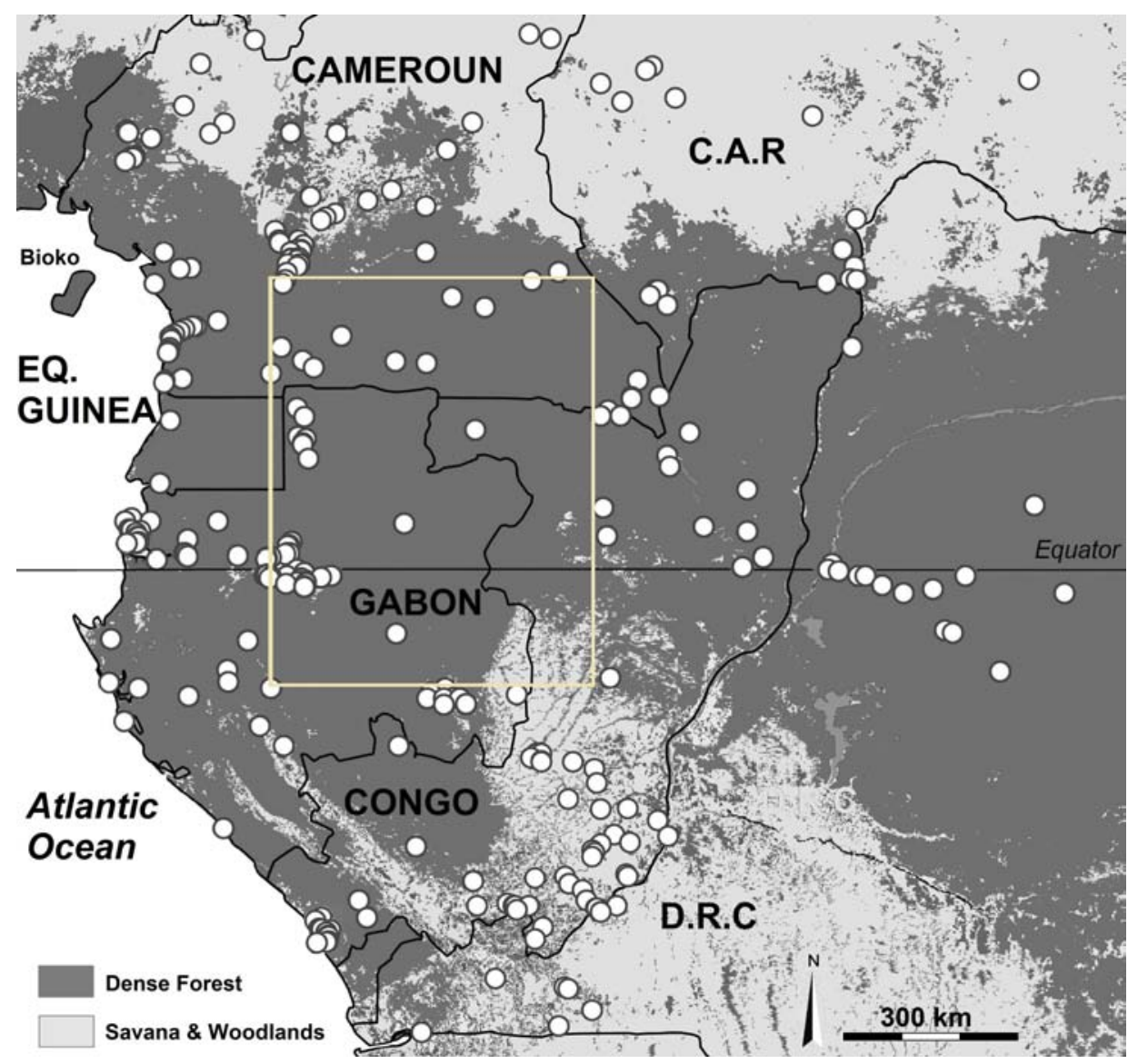

Figure 1 Location of the 328 dated archaeological sites in central Africa. The square indicates the forest hinterland between $4^{\circ} \mathrm{N}$ and $1^{\circ} 30^{\prime} \mathrm{S}$ and $10^{\circ} 30^{\prime} \mathrm{E}$ and $15^{\circ} 00^{\prime} \mathrm{E}$.

\section{METHODS}

We reviewed 54 papers that cite ${ }^{14} \mathrm{C}$ dates for archaeological sites for the period 5000 to $100 \mathrm{BP}$ and describe the associated cultural traditions (see the full data tables and references in the online Supplementary files: Appendices S1 and S2). This literature review is supplemented with 31 unpublished ${ }^{14} \mathrm{C}$ dates processed by the accelerator mass spectrometry (AMS) facilities of LMC14 Saclay, Poznań Radiocarbon Laboratory, Leibniz-Labor (Kiel), and Beta Analytic (Miami).

\section{RESULTS AND DISCUSSION}

The review of the literature combined with unpublished data allowed identifying $733{ }^{14} \mathrm{C}$ dates spanning 4 cultural periods. The database of human occupation sites is presented in Appendix S2. Among these dates, 16 have been rejected by the authors of the corresponding articles, 25 were modern dates, 94 were considered duplicates (very similar dates in the same site), and 12 correspond to the Bioko Island (Equatorial Guinea), specific to an isolated population that came in contact with Iron Age culture at the arrival of the Europeans during the 18th century. Hence, we refined the database by excluding these 147 dates on the basis of the above criteria, leading to a new database of 586 dates (Appendix S1 and S2) corresponding to 328 identified archaeological sites. 
West Central Africa: ${ }^{14}$ C Dates over Past 5000 Years

The data summarized in Table 1 confirm previous work (Clist 1995; de Maret 1985; Eggert 1993; Oslisly 1993, 2001; Wotzka 2006) showing an exponential increase in the number of sites and dates during the period 5000-100 cal BP, in particular during the Iron Age, which can be attributed to the expansion of the Bantu people.

Table 1 Distribution of the dated sites according to the material culture (see Appendix S1 and S2).

\begin{tabular}{|c|c|c|c|c|}
\hline Cultural periods & $\begin{array}{l}\text { End of Late Stone Age } \\
5000-3500 \text { cal BP }\end{array}$ & $\begin{array}{l}\text { Neolithic Stage } \\
3500-1900 \text { cal BP }\end{array}$ & $\begin{array}{l}\text { Early Iron Age } \\
2800-1000 \text { cal BP }\end{array}$ & $\begin{array}{l}\text { Late Iron Age } \\
1000-100 \text { cal BP }\end{array}$ \\
\hline Number of dates & 33 & 97 & 285 & 171 \\
\hline Number of sites & 27 & 64 & 182 & 128 \\
\hline $\begin{array}{l}\text { Number of sites with } \\
\text { long occupation }\end{array}$ & 8 & 23 & 52 & 26 \\
\hline
\end{tabular}

The combination of the ${ }^{14} \mathrm{C}$ dates with the analysis of the archaeological material (e.g. flaked and polished stones, pottery shape and decoration, iron tools) allowed assessing four cultural groups: the last hunter-gatherers of the LSA, the first sedentary population of the Neolithic stage and the metallurgists of EIA and LIA (Oslisly 2001), corresponding to 4 main groups of dates ranging between 5000-3500 cal BP (group 1), 3500-1900 cal BP (group 2), 2800-1000 cal BP (group 3) and 1000$100 \mathrm{cal}$ BP (group 4), respectively.

\section{Group 1: 5500-3500 cal BP}

This group corresponds to the end of the Late Stone Age, a long period that started $\sim 45,000 \mathrm{cal}$ BP (Oslisly et al. 2006), characterized by populations of hunter-gatherers that mastered stone-knapping with small stone tools as arrowheads, points, scrappers, and notched tools of quartz, jasper, and flint. Group 1 is represented at 27 sites with 33 dates. This period ceased with the arrival of the new migrants of the Neolithic stage.

\section{Group 2: 3500-1900 cal BP}

This group refers to the Neolithic Stage ranging between $3500 \mathrm{cal} \mathrm{BP}$ and $1900 \mathrm{cal}$ BP on the coast of Gabon and Congo. We use the term "Neolithic Stage" because it best explains the phase between the Late Stone Age and the Early Iron Age where people started to become sedentary, worked and polished stone tools, and made the first pottery. They used stone hoes and axes to create the first forms of slash-and-burn agriculture, which likely represented the first impacts on the forest. Some 64 excavations and 97 dates can be ascribed to this group.

Figure 2 reveals that this group resided in the Lopé National Park in Gabon (Oslisly and Fontugne 1993) and along the coast of the Congo near Pointe Noire (Denbow 2012), in contact with iron workers during $500 \mathrm{yr}$ and disappeared around $1900 \mathrm{cal} \mathrm{BP}$. This transition is confounded by the period known as the Hallstatt Plateau at 2450 BP (800-400 cal BC), which results in wide ranges of calibrated dates that make it impossible to obtain a detailed chronology.

\section{Group 3: $2800-1000$ cal BP}

While an apparent Iron Age is known around $2800 \mathrm{cal}$ BP, we observed an important increase in the number of dates only around 2000-1700 cal BP, which indicates a demographic explosion of iron workers (Figure 2). This long period, from 2800 to 1000 cal BP, is known as the Early Iron Age and is represented by 285 dates collected in 182 sites. These iron workers generally settled on hilltops, constructed iron reduction furnaces in clay near villages, and manufactured pottery of diverse shapes and decorations. They also practiced slash-and-burn agriculture by creating clearings in the 


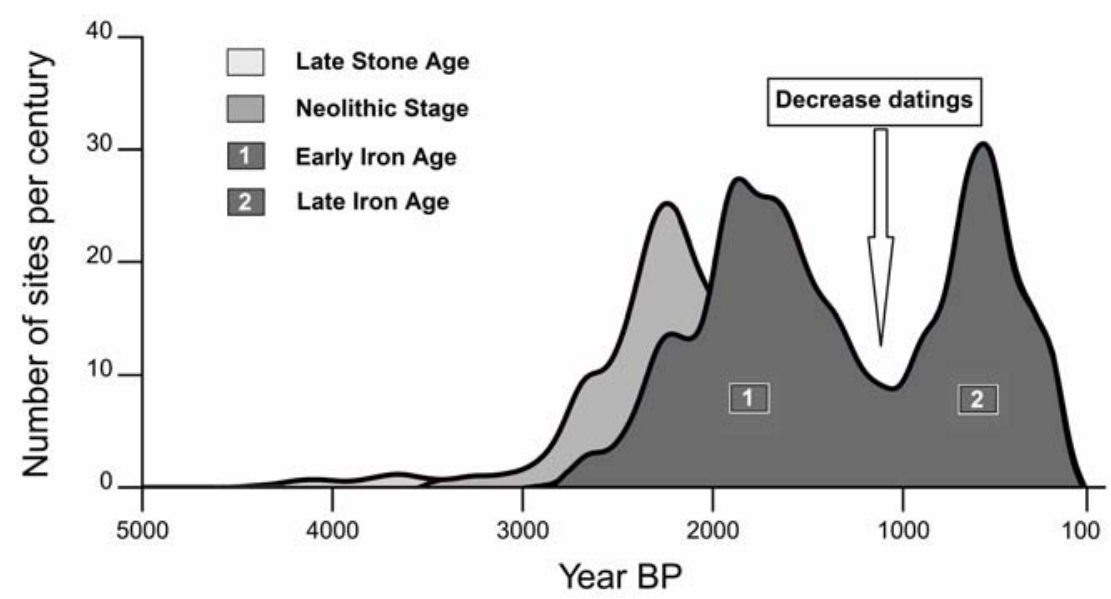

Figure 2 Temporal distribution of the radiocarbon dates from 5000-100 cal BP and the corresponding cultural traditions.

forest with more efficient iron tools (Oslisly 1998). From 1600 to 1000 cal BP, there is a significant decrease in the number of dates (Oslisly 2001; Wotzka 2006). It is important to note that this decrease is characterized by a total absence of dates between 1350 to $860 \mathrm{cal}$ BP in the area of the forest hinterland situated between $4^{\circ} \mathrm{N}$ and $1^{\circ} 30^{\prime} \mathrm{S}$ and $10^{\circ} 30^{\prime} \mathrm{E}$ and $15^{\circ} 00^{\prime} \mathrm{E}$ (Figure 1). The characterization of this hiatus, described as a "population crash" (Oslisly 2001), relies on at least 76 dates covering the period from 2400 to 100 cal BP (Figure 3).

This area is not neglected and has been the subject of archaeological surveys and excavations during the last decade (Oslisly 2006; Eggert et al. 2006; Meister and Eggert 2008; Meister 2010 for southwest and south Cameroon; Oslisly and De Saulieu current fieldwork in the Sangmelima/Djoum/ Mbalam/Souanké in southern Cameroon and northern Congo; Morin-Rivat in southeast Cameroon and northern Congo; Oslisly and Assoko 2007 in central Gabon). Archaeological research under our supervision has also started in northern Gabon in order to connect the studied areas of central Gabon and southern Cameroon.

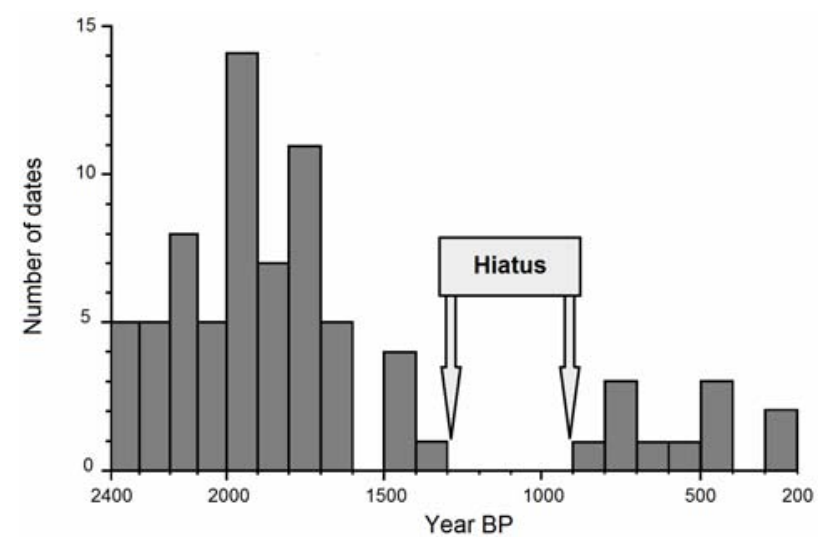

Figure 3 Temporal distribution of the 76 dates of the forest hinterland (see limits on Figure 1) showing the hiatus. 
West Central Africa: ${ }^{14} \mathrm{C}$ Dates over Past 5000 Years

\section{Group 4: $1000-100$ cal BP}

The Late Iron Age (LIA) started gradually from 1000 cal BP and reached a maximum number of dates around 500 cal BP. After this peak, the dates decreased until the colonial period. In this central forest block, the LIA is characterized by the establishment of migrant populations having originated from the north, east, and south. They practiced new techniques for iron reduction, with the pit furnace made up of long tubes. Their pottery, often decorated by rolled impressions with wooden roulette or braided cord roulette, are less diversified than those of the EIA (Oslisly 1998). This pottery manufacture ceased at the outset of commercial exchanges with Europe from the 18th century with the introduction of crockery. Group 4 is described by 128 excavation sites and 171 dates.

\section{CONCLUSION}

${ }^{14} \mathrm{C}$ dating, as a fundamental aspect in human sciences, allowed us to recognize a cultural sequence from a foraging stage with stone flakes to a sedentary stage with pottery. During this later phase, people built villages on hilltops; mastered arts of fire, pottery, and metallurgy of iron; and practiced slash-and-burn agriculture. Despite the difficulties in fieldwork and accessing the archaeological sites in these remote forest regions and the cost of the ${ }^{14} \mathrm{C}$ dating, the pioneer work of de Maret (1985), Oslisly (1993), Eggert (1993), and Clist (1995) has increased our understanding of these ancient populations. New and ongoing research will help to complement the earlier work for this region.

\section{ACKNOWLEDGMENTS}

This research was funded by the ERA-Net BiodivERsA (CoForChange project), with the national funders ANR (France) and NERC (UK), part of the 2008 BiodivERsA call for research proposals. Other funding were also provided by the EU program ECOFAC (1992-1998), IRD Projects (ECOFIT 1992-1996, PALEOFORGA 1997-1999, ADHENTRO 2000-2005, PALOC 2008-2012, PPR-FTH since 2011) and CNRS projects (PNEDC PRIMUS 2002-2004 and ECLIPSE REGAB 2005-2009). We want to thank C Moreau and J-P Dumoulin of the LMC14 Artemis AMS facility (Saclay, France) and Connie Meister for his contribution to the review of the archaeological dates.

\section{REFERENCES}

Clist B. 1995. Gabon: 100.000 ans d'Histoire. Paris: Sépia Edition.

de Maret P. 1985. Recent archaeological research and dates from central Africa. The Journal of African History 26(2-3):129-48.

Denbow J. 2012. Pride, prejudice, plunder and preservation: archaeology and the re-envisioning of ethnogenesis on the Loango coast of the Republic of Congo. Antiquity 86(332):383-408.

Eggert M. 1993. Central Africa and the archaeology of the equatorial rainforest: reflections on some major topics. In: Shaw T, Sinclair P, Andah B, Okpoko A, editors. The Archaeology of Africa: Food, Metals and Towns. London: Routledge. p 289-329.

Eggert M, Hohn A, Kahlheber S, Meister C, Neumann K, Schweizer S. 2006. Pits, graves and grains: archaeological and archaeobotanical research in southern Cameroon. Journal of African Archaeology 4(2):27398.

Meister C. 2010. Remarks on Early Iron Age burial sites from southern Cameroon. African Archaeological Review 27(3):237-49.

Meister C, Eggert MKH. 2008. On the early Iron Age in southern Cameroon: the sites of Akonétye. Journal of African Archaeology 6(2):183-202.

Oslisly R. 1993. Préhistoire de la moyenne vallée de l'Ogooué au Gabon. Paris: Editions de l'Orstom.

Oslisly R. 1998. Hommes et milieux à l'Holocène dans la moyenne vallée de l'Ogooué au Gabon. Bulletin de la Société Préhistorique Française 95(1):93-105.

Oslisly R. 2001. The history of human settlement in the middle Ogooué valley (Gabon): implications for the environment. In: Weber W, White LJT, Vedder A, Naugthon-Treves L, editors. African Rain Forest Ecology and Conservation. New Haven: Yale University Press. p 101-18.

Oslisly R. 2006. Les traditions culturelles de l'Holocène sur le littoral du Cameroun entre Kribi et Campo. In: 


\section{$R$ Oslisly et al.}

Wotzka HP, editor. Grundlegungen. Beiträge zur europäischen und afrikanischen Archäologie für Manfred K.H. Eggert. Tübingen: Francke Attempto Verlag GmbH. p 303-17.

Oslisly R, Assoko A. 2007. Archéologie de sauvetage sur la route Médoumane Lalara. Vallée de l'Okano - Gabon. Libreville: WCS Editions.

Oslisly R, Fontugne M. 1993. La fin du stade néolithique et le début de l'âge du fer dans la moyenne vallée de l'Ogooué au Gabon. Problèmes chronologiques et changements culturels. Comptes rendus de l'Académie des Sciences de Paris 316(II):997-1003.

Oslisly R, Doutrelepont H, Fontugne M, Giresse P, Hatté
C, White L. 2006. Premiers résultats d'une stratigraphie vieille de plus de 40.000 ans du site de Maboué 5 dans la réserve de la Lopé. In: Actes $d u X I V^{\circ}$ Congrès de l'UISPP. Liège 2-8 September 2001, Préhistoire en Afrique. British Archaeological Reports, International Series 1522. Oxford: Archaeopress. p 189-98.

Wotzka HP. 2006. Records of activity: radiocarbon and the structure of iron age settlement in central Africa. In: Wotzka HP, editor. Grundlegungen. Beiträge zur europäischen und afrikanischen Archäologie für Manfred K.H. Eggert. Tübingen: Francke Attempto Verlag GmbH. p 271-89. 